\title{
Pengaruh Paparan Hipoksia terhadap Aktivitas Antioksidan Katalase dan Kadar Malondialdehid (MDA) pada Jaringan Hati Tikus
}

\section{The Influence of Hypoxia Exposure toward Catalase Antioxidant Activity and Malondialdehyde (MDA) Content in Rat Liver Tissue}

\author{
Amanda Putri Lestari, Tri Murtiati, Rini Puspitaningrum
}

Corresponding author; email: rini_puspitaningrum@yahoo.com

\begin{abstract}
Hypoxia is a condition with inadequate $\mathrm{O}_{2}$ content in the tissue. Hypoxia can make the formation of free radicals or reactive oxygen species (ROS) which reactive to cell membrane. Body will avoid free radicals by producing antioxidant, such as catalase enzyme. The reaction between ROS and cell membrane will form malondialdehyde (MDA). Liver is the main location of catalase. This research was aimed to know the influence of hypoxia exposure toward catalase antioxidant activity and MDA content in the rat liver tissue. This research used experiment method with fully randomized design. Based on one way Anova test $(\mathrm{p} \leq 0.01)$, it was shown that there had no average difference on catalase activity and MDA content toward length hypoxia exposure. The conclusion of this research was no influence of hypoxia exposure toward catalase activity and MDA content in rat liver tissue.
\end{abstract}

Key words: catalase antioxidant activity, hypoxia, malondialdehyde (MDA) content, rat liver tissue

\section{Pendahuluan}

Salah satu kebutuhan utama yang dapat menunjang kehidupan organisme adalah oksigen $\left(\mathrm{O}_{2}\right.$. Molekul $\mathrm{O}_{2}$ sangat berperan bagi kehidupan organisme khususnya organisme multiseluler seperti tumbuhan, hewan, dan manusia karena elemen inilah energi bebas dapat dihasilkan melalui respirasi aerob. Oksigen diketahui terdapat di udara (atmosfer) dan di perairan. Kadar normal $\mathrm{O}_{2}$ di atmosfer adalah sekitar 21\% atau $160 \mathrm{~mm} \mathrm{Hg}$ (Sherwood, 2010). Hipoksia merupakan kondisi rendahnya kadar $\mathrm{O}_{2}$ yang terdapat dalam sel / jaringan hingga di bawah tingkat fisiologis (Hadiarto, 2010). Kadar oksigen dalam sel / jaringan dapat dikatakan hipoksia apabila tekanan parsial gas (Pgas) oksigen (PO ) dalam darah arteri $<100 \mathrm{mmHg}$ karena terdapat $<20 \%$ gas $\mathrm{O}_{2}$ di dalam udara atmosfer (Law, 1999).

Tidak tersedianya kadar $\mathrm{O}_{2}$ yang cukup di dalam jaringan akan mengganggu stabilitas respirasi aerob dalam sel khususnya pada tahap transpor elektron. Pada tahap ini dibutuhkan molekul $\mathrm{O}_{2}$ sebagai penerima terakhir elektron. Akibat tidak tercukupinya molekul $\mathrm{O},{ }_{2}$ maka akan menghasilkan elektron-elektron bebas yang bersifat tidak stabil atau dikenal sebagai radikal bebas. Elektron tidak stabil ini akan berperan sebagai Reactive Oxygen Species (ROS). Salah satu ROS yang secara alami dihasilkan oleh tubuh adalah hidrogen peroksida $\left(\mathrm{H}_{2} \mathrm{O}_{2}\right)$.

Secara alamiah, tubuh dapat melakukan upaya protektif dari pengaruh negatif ROS.

Cara yang dilakukan tubuh untuk mengatasi jumlah radikal bebas adalah dengan memproduksi antioksidan salah satunya adalah katalase. Katalase adalah antioksidan golongan enzim yang dapat mengubah $\mathrm{H} \mathrm{O}$ menjadi air $(\mathrm{H} \mathrm{O})$ dan $\mathrm{O}$. Selain itu, oksidatif stres akan memicu ROS melakukan reaksi peroksida lemak yang akan merusak sel / jaringan. $\mathrm{H} \mathrm{O}_{2}^{2} 2_{2}^{2}$ merupakan jenis ROS yang sangat reaktif terhadap membran sel. Salah satu produk akhir dari reaksi lemak peroksida adalah terbentuknya senyawa malondialdehid (MDA), sehingga tingkat kerusakan sel dapat diukur berdasarkan kadar MDA yang terdapat dalam sel / jaringan. Organ hati merupakan lokasi utama keberadaan katalase (Kyo Ah Kang et al., 2006). Hal ini sesuai dengan tugas utama organ hati sebagai penetralisir racun seperti radikal bebas yang terdapat di dalam tubuh. 


\section{Metode Penelitian}

1. Sampel penelitian

Tikus wistar jantan (Rattus norvegicus) yang digunakan sebanyak 24 ekor berdasarkan rumus Frederer. Sampel tersebut didapat dari Badan Penelitian Veteriner (BALITVET), Bogor dengan kriteria umur 2.5 - 3 bulan dan berat \pm 100 gr.

2. Aklimatisasi Tikus

Kandang disiapkan untuk setiap ekor tikus yang terdiri dari baki berukuran $15 \times 30 \mathrm{~cm}$ berisi sabut kayu oven secukupnya, pakan tikus dengan dosis 15 gr/ekor/hari, kawat penutup berukuran 20 x $40 \mathrm{~cm}$, serta air minum dalam botol. Sabut kayu diganti setiap 4 hari sekali. Baki diganti setiap satu minggu sekali. Seluruh tikus diaklimatisasi selama 2 minggu di ruang kandang Animal House Biologi UNJ sebelum diberikan perlakuan.

3. Kelompok Paparan Hipoksia

Satu set hypoxic chamber disiapkan lalu dihubungkan dengan selang plastik ke tabung gas yang berisi $\mathrm{O}_{2} \quad 10 \%$ dan $\mathrm{N}_{2}$ 90\%. Sabut kayu oven dimasukkan secukupnya ke dalam chamber. Pakan tikus dimasukkan sebanyak 60 gr dan air minum. 4 ekor tikus wistar jantan yang telah diaklimatisasi diambil, ditimbang, dicatat berat badan tikus dan diberikan tanda menggunakan asam pikrat. Sejumlah 4 ekor tikus tersebut dimasukkan ke dalam chamber dan menutup rapat chamber. Dialirkan gas $\mathrm{O}_{2} 10 \%$ dan $\mathrm{N}_{2} 90 \%$ dengan kecepatan $1 \mathrm{~L} /$ menit ke dalam chamber. Pengaliran gas ke dalam chamber sesuai dengan waktu pemaparan (length exposure) yakni 1,3,7,14,dan 21 hari. Pemeliharaan dilakukan dengan mengganti sabut kayu oven dan air minum 2x sehari (pagi dan sore), mengelap uap pada dinding chamber, memberikan pakan tikus dengan dosis $60 \mathrm{gr} / \mathrm{hari}$.

4. Kelompok Kontrol

Satu set kandang disiapkan untuk tiap ekor tikus. Berat badan tikus ditimbang dan diberikan tanda menggunakan asam pikrat. Pemeliharaan tikus di ruangan kontrol selama 21 hari. Pemeliharaan dilakukan dengan mengganti sabut kayu oven seminggu sekali, pemberian pakan tikus $15 \mathrm{gr} / \mathrm{hari}$, dan air minum ad libitum.

5. Pembedahan Tikus

Setiap ekor tikus dikeluarkan dari chamber / kandang bila telah mencapai hari paparan hipoksia. Tikus dimatikan dengan cara dislokasi leher. Diukur dan dicatat perubahan berat badan. Tikus dibedah lalu diambil darah melalui ventrikel jantung menggunakan syringe $2.5 \mathrm{cc}$ yang berisi heparin. Darah tersebut akan dilakukan pengukuran gas darah menggunakan jasa Lab. IKA FKUI/RSCM Intensive Care Unit. Parameter yang dibutuhkan untuk menggambarkan kondisi hipoksia adalah nilai $\mathrm{pH}, \mathrm{pCO}_{2}$, dan $\mathrm{pO}_{2}$. Organ hati disimpan dalam freezer $-20{ }^{\circ} \mathrm{C}$.

6. Pembuatan Protein Homogenat Hati Tikus

Jaringan hati tikus kelompok perlakuan dan kontrol ditimbang masing-masing $1 \mathrm{gr}$. Jaringan dicuci menggunakan PBS + PMSF hingga bersih dari darah lalu ditambahkan PBS + PMSF sebanyak $150 \mu$ l. Jaringan tersebut dilumat menggunakan pestle lalu ditambahkan PBS + PMSF dengan perbandingan 1 : 1. Larutan homogenat disentrifus dalam $12.000 \mathrm{rpm}$ $4^{\circ} \mathrm{C}$ selama 10 menit lalu dipisahkan antara pelet dan supernatan. Supernatan inilah yang akan dijadikan protein homogenat yang kemudian disimpan dalam freezer $-20{ }^{\circ} \mathrm{C}$ hingga tahap uji aktivitas katalase dan kadar MDA.

7. Uji Aktivitas Katalase

Supernatan di encerkan menggunakan PBS+PMSF dengan perbandingan 1:500. Larutan $\mathrm{H} \mathrm{O} 10 \mathrm{mM}$ diencerkan dengan menggunakan dapar fosfat dengan perbandingan $1: 100$. Kuvet $\mathrm{spe}^{2} \mathrm{2}^{2}$ trofotometer UV disiapkan. Pada kuvet blanko dimasukkan PBS sebanyak $50 \mu \mathrm{l}$ dan $\mathrm{H}_{2} \mathrm{O}_{2}$ sebanyak $950 \mu$ 1. Pada kuvet uji dimasukkan supernatan yang telah diencerkan sebanyak $50 \mu 1$ dan $\mathrm{HO}^{\mathrm{O}}$ sebanyak $950 \mu \mathrm{l}$ lalu dicampurkan secara manual. Menggunakan panjang gelombang 240nm masing-masing kuvet diukur absorbansi pada menit pertama $(\mathrm{t})$ dan menit ke dua $(\mathrm{t})$. Aktivitas katalase $(\mathrm{U} / \mathrm{mL})$ ditentukan berdasarkan rumus sebagai berikut: 


\section{$\Delta$ Absorbansi Uji $-\Delta$ Absorbansi Blanko \\ Molaritas $\mathrm{H}_{2} \mathrm{O}_{2} \mathrm{X}$ Volume $\quad x$ Faktor sampel Pengencer}

8. Uji Kadar MDA dengan Metode Wills.

Tabung falcon disiapkan. 1 buah tabung dijadikan sebagai blanko yang berisi $750 \mu 1$ akuadest dan TCA $20 \%$ sebanyak $375 \mu 1.4$ buah tabung dijadikan sebagai uji standar yang berisi larutan sesuai Tabel 1 di bawah ini.

Tabel 1. Komposisi uji standar kadar MDA

\begin{tabular}{cccc}
\hline \multirow{2}{*}{ Standar $(\mathrm{nmol} / \mathrm{ml})$} & \multicolumn{3}{c}{ Larutan $(\mu \mathrm{l})$} \\
\cline { 2 - 4 } & Standar Tetraetoksipopran & TCA 20\% & Akuadest \\
\hline 0.23 & 9.375 & 375 & 750 \\
0,45 & 18.75 & 375 & 750 \\
0,93 & 37.5 & 375 & 750 \\
1.86 & 75 & 375 & 750 \\
\hline
\end{tabular}

Tabung falcon lainnya disiapkan untuk digunakan sebagai uji kelompok kontrol ataupun perlakuan beserta masing-masing replikasinya. Tabung tersebut berisi $750 \mu$ l protein homogenat dan $375 \mu 120 \%$ TCA. Seluruh tabung reaksi tersebut (blanko, standar duplo, dan uji kontrol/ perlakuan) masing-masing divortex hingga homogen lalu di sentrifus $3000 \mathrm{rpm}$ selama 10menit. Setelah disentrifus, diambil supernatannya dan masing-masing ditambahkan 750 $\mu 1$ TBA $0.67 \%$. Kuvet yang berisi larutan tersebut dipanaskan dalam penangas air yang bersuhu $95^{\circ}-100^{\circ} \mathrm{C}$ selama 10menit kemudian didinginkan dalam bejana berisi air es lalu dibaca serapan pada panjang gelombang 530nm. Untuk mengetahui kadar MDA ( $\mathrm{nmol} / \mathrm{ml})$, dilakukan perhitungan dengan rumus dibawah ini:

\section{$\frac{\text { Absorbansi kuvet uji }}{\text { Absorbansi kuvet standar }} \times$ Kadar standar}

\section{Teknik Analisis Data}

Data utama berupa aktivitas antioksidan katalase, kadar MDA jaringan hati tikus secara spektrofotometri diuji normalitas (Kolmogorov-Smirnov) dan Anova 1 arah ( $\mathrm{p} \leq 0.01)$ menggunakan SPSS 17.

\section{Hasil}

1. Berat badan tikus hewan coba

Berdasarkan Gambar 1 berat badan tikus kelompok perlakuan terlihat semakin menurun sesuai dengan lama waktu pemaparan gas $\mathrm{O}_{2} \quad 10 \%$ di dalam chamber. Nilai penurunan berat badan minimum tikus kelompok perlakuan adalah pada pemeliharaan 3 hari, yaitu rata-rata 4,25 gr. Sedangkan nilai penurunan berat badan terendah adalah pada pemeliharaan 21 hari, yaitu setinggi 14,25 gr. Tikus kelompok kontrol mengalami peningkatan berat badan setinggi 49 gr. Perubahan berat badan tikus dapat ditinjau pada Gambar 1.

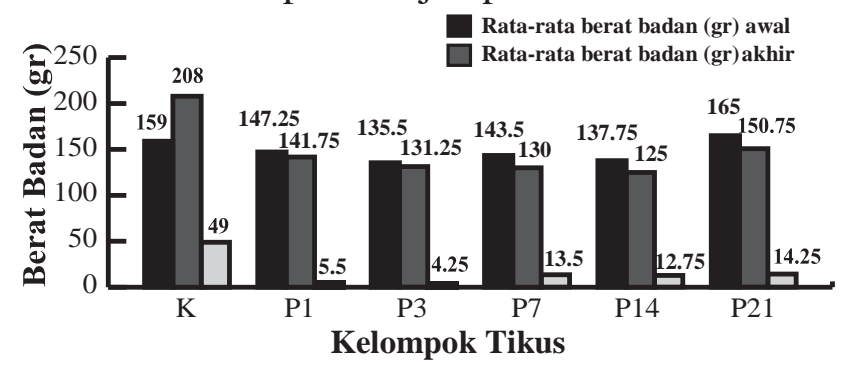

Gambar 1. Perubahan Berat Badan Tikus; $\mathrm{K}=$ Tikus Kelompok Kontrol; $\mathrm{P}=$ Tikus Kelompok Perlakuan dengan pemaparan gas $\mathrm{O}_{2} 10 \% ; 1,3,7,14,21=$ Lama pemaparan gas $\mathrm{O}_{2} 10 \%$ (hari). 
2. Profil gas darah tikus hewan coba

Pengujian gas darah pada tikus selama penelitian adalah mendapatkan profil $\mathrm{pH}, \mathrm{pO}$ dan $\mathrm{pCO}_{2}$. Darah tikus normal memiliki nilai $\mathrm{pH} 7,25-7,35 ; \mathrm{pCO}_{2} 32-43 \mathrm{mmHg}$, pO $20_{-}^{2}$ $100 \mathrm{mmHg}$ (Heeijnen, 2002). Berdasarkan Tabel 2, telah diperoleh hasil pengukuran gas darah tikus antara kelompok perlakuan dengan kelompok kontrol. Nilai $\mathrm{pH}$ darah tikus kelompok perlakuan semakin rendah seiring dengan lama pemaparan gas $\mathrm{O}_{2} 10 \%$. Pada hasil pengukuran $\mathrm{pH}$ darah tikus kelompok kontrol menunjukkan nilai 7,1. Nilai $\mathrm{pH}$ darah tikus kelompok kontrol menunjukkan nilai yang lebih rendah bila dibandingkan dengan $\mathrm{pH}$ standar tikus normal. Namun, jika dibandingkan dengan nilai $\mathrm{pH}$ darah tikus kelompok perlakuan maka nilai $\mathrm{pH}$ tikus kelompok kontrol masih lebih tinggi.

Nilai kadar $\mathrm{pCO}_{2}$ tikus kelompok perlakuan memiliki nilai yang lebih tinggi daripada kadar $\mathrm{pCO}_{2}$ tikus kelompok kontrol. Namun, pada pemaparan gas $\mathrm{O}_{2} 10 \% 14$ hari, kadar $\mathrm{pCO}_{2}$ tikus kelompok perlakuan menunjukkan nilai yang sangat rendah bila dibandingkan dengan kelompok kontrol. Hasil pengukuran kadar pCO darah tikus kelompok kontrol adalah 58 mmHg. Nilai kadar $\mathrm{pCO}_{2}$ darah tikus kelompok kontrol ini menunjukkan nilai yang lebih tinggi bila dibandingkan dengan $\mathrm{pCO}_{2}$ standar tikus normal. Peningkatan nilai $\mathrm{pCO}_{2}$ darah tikus kelompok perlakuan sesuai dengan semakin lamanya waktu pemaparan gas $\mathrm{O}_{2} 10 \%$. Pada Tabel 2 dapat ditinjau hasil pengukuran gas darah tikus selama penelitian.

Hasil pengukuran kadar $\mathrm{pO}_{2}$ darah tikus kelompok kontrol adalah 25,5 mmHg. Kadar $\mathrm{pO}_{2}$ darah tikus kelompok kontrol menunjukkan nilai yang lebih rendah bila dibandingkan dengan $\mathrm{pO}_{2}$ standar tikus normal. Nilai kadar $\mathrm{pO}_{2}$ tikus kelompok perlakuan tidak berbeda jauh dari $\mathrm{pO}_{2}$ kelompok kontrol.

Tabel 2. Hasil Pengukuran Gas Darah Tikus Kelompok Perlakuan; K = Tikus Kelompok Kontrol; $\mathrm{P}=$ Tikus Kelompok Perlakuan dengan pemaparan gas $\mathrm{O}_{2} 10 \% ; 1,3,7,14,21=$ Lama pemaparan gas $\mathrm{O}_{2} 10 \%$ (hari).

\begin{tabular}{cccc}
\hline \multicolumn{4}{c}{ Parameter } \\
\hline Label & $\mathrm{pH}$ & $\mathrm{pCO}_{2}(\mathrm{mmHg})$ & $\mathrm{pO}_{2}(\mathrm{mmHg})$ \\
\hline Standar $*$ & $7,25-7,35$ & $32-43$ & $50-100$ \\
$\mathrm{~K}$ & 7.1 & 58 & 25.5 \\
$1 \mathrm{H}$ & 7,1 & 75,25 & 33,5 \\
$3 \mathrm{H}$ & 7 & 82,52 & 13,32 \\
$7 \mathrm{H}$ & 7,023 & 43,825 & 24,725 \\
$14 \mathrm{H}$ & 7,02 & 95,725 & 24,475 \\
$21 \mathrm{H}$ & 6,7 & 94,95 & 27,97 \\
\hline
\end{tabular}

Keterangan * : Standar analisis gas darah tikus normal berdasarkan Heijnein et al, 2002.

3. Aktivitas Katalase

Telah diperoleh nilai aktivitas katalase antara tikus kelompok perlakuan dengan kelompok kontrol. Tikus kelompok perlakuan menunjukkan nilai aktivitas katalase yang lebih tinggi namun mengalami fluktuasi selama penelitian berlangsung. Aktivitas antioksidan katalase tertinggi terjadi pada pemaparan 3 hari, yaitu setinggi 126,75 Unit/ml. Nilai aktivitas katalase semakin menurun pada paparan 7 dan 14 hari namun kembali meningkat pada 21 hari, yaitu setinggi 92,25 Unit/ml. Nilai aktivitas antioksidan katalase pada tikus kelompok perlakuan lebih tinggi daripada tikus kelompok kontrol.

Berdasarkan hasil uji normalitas (Kolmogorov-Smirnov) data aktivitas katalase berdistribusi normal. Hasil uji statistik Anova 1 arah $(\mathrm{p} \leq 0.01)$ menunjukkan $\mathrm{F}$ tabel sebesar 1.343 sedangkan $\mathrm{F}$ hitung adalah 0.701 . Oleh karena $\mathrm{F}$ hitung $<\mathrm{F}$ tabel maka dapat dikatakan bahwa bahwa tidak ada perbedaan rata-rata aktivitas antioksidan katalase jaringan hati tikus 
terhadap setiap lama pemaparan $\mathrm{O}_{2} \quad 10 \%(1,3,7,14$, dan 21 hari). Nilai aktivitas antioksidan katalase jaringan hati tikus kelompok perlakuan dapat ditinjau pada Gambar 2.

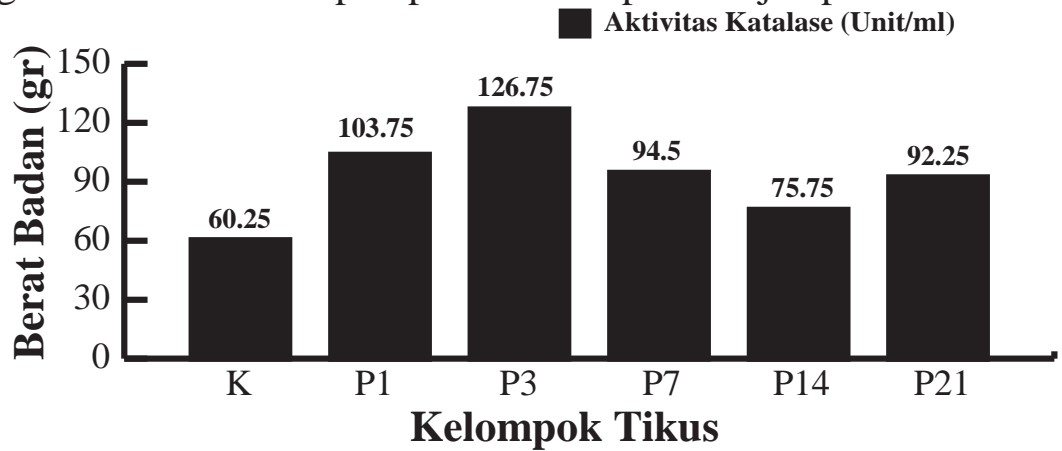

Gambar 2. Aktivitas Katalase (Unit/ml) Jaringan Hati Tikus. K = Tikus Kelompok Kontrol;

$\mathrm{P}=$ Tikus Kelompok Perlakuan dengan pemaparan gas $\mathrm{O}_{2} 10 \%$;

$1,3,7,14,21=$ Lama pemaparan gas $\mathrm{O}_{2} 10 \%$ (hari).

4. Profil kadar malondialdehid (MDA) jaringan hati tikus coba selama penelitian

Tikus kelompok perlakuan memperlihatkan nilai kadar MDA yang lebih tinggi bila dibandingkan dengan nilai kadar MDA tikus kelompok kontrol. Namun nilai kadar MDA kelompok perlakuan mengalami fluktuasi selama penelitian sampai 21 hari. Pada tikus kelompok perlakuan, nilai kadar MDA lebih rendah pada paparan 3 hari, yaitu setinggi 0,836 $\mathrm{nmol} / \mathrm{ml}$ dan pada paparan 14 hari, yaitu setinggi $0,856 \mathrm{nmol} / \mathrm{ml}$. Nilai kadar MDA tertinggi tikus kelompok perlakuan terjadi pada lama pemaparan 7 hari, yaitu setinggi 1,417 $\mathrm{nmol} / \mathrm{ml}$. Kadar MDA jaringan hati tikus dapat dtinjau pada Gambar 3.

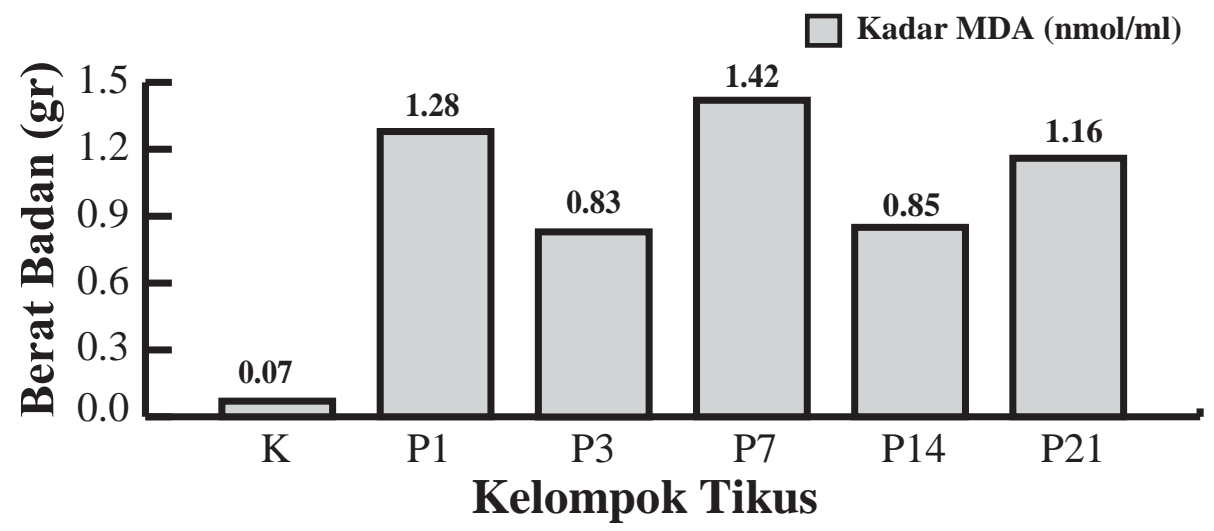

Gambar 3. Kadar Mmalondialdehid (nmol/ml) Jaringan hati tikus. $\mathrm{K}=$ Tikus Kelompok Kontrol; $\mathrm{P}=$ Tikus Kelompok Perlakuan dengan pemaparan gas $\mathrm{O}_{2} 10 \%$; $1,3,7,14,21=$ Lama pemaparan gas O2 10\% (hari).

Berdasarkan hasil uji normalitas (Kolmogorov-Smirnov) data kadar MDA berdistribusi normal. Hasil uji statistik anova 1 arah $(\mathrm{p} \leq 0.01)$ menunjukkan $\mathrm{F}$ tabel sebesar 4.25 sedangkan $\mathrm{F}$ hitung adalah 1.343. Oleh karena $\mathrm{F}$ hitung $<\mathrm{F}$ tabel maka dapat dikatakan bahwa bahwa tidak ada perbedaan rata-rata kadar MDA jaringan hati tikus terhadap lama pemaparan $\mathrm{O} 210 \%$ $(1,3,7,14$, dan 21 hari).

\section{Pembahasan}

1. Profil Perubahan Berat Badan Tikus

Data berat badan, tikus kelompok perlakuan cenderung mengalami penurunan berat badan sesuai dengan lama pemaparan. Kelompok perlakuan menghasilkan penurunan berat badan dengan hasil terendah terjadi pada pemeliharaan selama 3 hari dengan rerata 4,25 gr dan hasil tertinggi pada pemeliharaan selama 21 hari sebesar 14,25 gr. Penurunan berat badan pada kelompok perlakuan mungkin disebabkan oleh tidak terpenuhinya kebutuhan $\mathrm{O}_{2}$. 
Berdasarkan penelitian yang dilakukan oleh Chen (2007), bahwa kondisi hipoksia akan menyebabkan penurunan berat badan. Beberapa teori pendukung hal ini adalah efek dari tingginya kadar reactive oxygen species (ROS) dan peristiwa program kematian sel. ROS bersifat reaktif terhadap konstituen sel seperti DNA dan membran sel. ROS dapat merusak membran sel dengan cara mengambil elektron yang berada di membran sel sehingga membran sel akan menurun stabilitasnya (Catala, 2011). Peristiwa ini dikenal sebagai peroksidasi lemak dan menyisakan senyawa akhir berupa aldehid atau malondialdehid (MDA).

Penurunan berat badan akibat kondisi hipoksia merupakan hal yang telah diteliti. Beberapa faktor yang menyebabkan hal ini terjadi adalah meningkatnya laju metabolisme, menurunnya pemakaian energi, dan munurunnya asupan nutrisi karena berkurangnya nafsu makan (Liippl et al., 2009). Selain itu, menurunnya berat badan saat kondisi hipoksia disebabkan oleh penggunaan jaringan adiposa sebagai sumber energi, karena menurunnya asupan makan (Ge et al., 2001).

\section{Profil Gas Darah Tikus}

Berdasarkan hasil analisis gas darah pada tikus kelompok perlakuan, sesuai dengan lama pemaparan $\mathrm{O}_{2} 10 \%$, nilai $\mathrm{pH}$ semakin menurun, yakni dengan rata-rata 6,7 pada 21 hari. Tinggi rendahnya nilai $\mathrm{pH}$ dalam plasma darah bergantung pada sejumlah molekul $\mathrm{HCO}_{3}$-yang larut dalam darah (Sherwood, 2010). Hasil akhir dari metabolisme adalah terbentuknya $\mathrm{CO}_{2}$. Molekul ini harus segera dikeluarkan dari tubuh melalui aliran darah menuju paru-paru. Saat mengalir di aliran darah, $\mathrm{CO}_{2}$ akan berikatan dengan air menjadi ion $\mathrm{HCO}_{3}^{-}$. Tingginya kadar ion $\mathrm{HCO}_{3}^{-}$akan menurunkan nilai $\mathrm{pH}$.

Nilai $\mathrm{pCO}_{2}$ tikus kelompok perlakuan menunjukkan nilai yang lebih besar dari $\mathrm{pCO}_{2}$ standar tikus normal. $\mathrm{pCO}_{2}$ tertinggi terjadi pada lama pemaparan selama 14 hari yakni sebesar $95,7 \mathrm{mmHg}$. Nilai pCO ${ }_{2}$ paling rendah terjadi lama pemaparan selama 7 hari, hal ini dimungkinkan pada hari tersebut tikus mampu melakukan homeostatis terhadap CO . Nilai pCO diakibatkan oleh hasil kedua dari respirasi anaerob yang lebih tinggi akan membuat tikus melakukan adaptasi dengan melakukan hiperventilasi. Saat suplai $\mathrm{O}_{2}$ tidak terpenuhi, maka tubuh akan beradaptasi dengan melakukan respirasi anaerob. Respirasi anaerob ini bertujuan untuk memenuhi kebutuhan ATP. Hasil akhir dari respirasi anaerob adalah pembentukan asam laktat dan ion $\mathrm{H}^{+}$. Meningkatnya ion $\mathrm{H}^{+}$berhubungan dengan produksi $\mathrm{CO}_{2}$ di jaringan. Alasan signifikan mengenai meningkatnya $\mathrm{pCO} 2$ saat ini masih menjadi perdebatan, mengingat $\mathrm{CO}_{2}$ dapat terbentuk baik dari respirasi aerob atau respirasi anaerob (Guiterrez, 2004). Selain respirasi anaerobik, teori pendukung yang menjelaskan peningkatan $\mathrm{pCO}$ adalah kurva disosiasi dan aliran darah di jaringan. Kondisi hipoksia menyebabkan $\mathrm{pH}$ plasma menjadi asam sehingga meningkatkan afinitas hemoglobin untuk berikatan dengan $\mathrm{CO}_{2}$ sehingga meningkatkan pula nilai $\mathrm{pCO}_{2}$ (Vallet et al., 2000).

Nilai $\mathrm{pO}_{2}$ darah tikus kelompok perlakuan menunjukkan hasil yang berbeda dengan nilai $\mathrm{pO}_{2}$ kontrol. Rendahnya nilai $\mathrm{pO}_{2}$ kontrol dimungkinkan $\mathrm{pO}_{2}$ atmosfernya memang rendah. Sedangkan rendahnya nilai $\mathrm{pO}_{2}$ perlakuan disebabkan oleh persentase gas $\mathrm{O}_{2}$ yang diberikan hanya $10 \%$, sehingga akan semakin menurunkan $\mathrm{pO}_{2}$ di peredaran darah. Saat mencapai peredaran darah, nilai $\mathrm{pO}_{2}$ di atmosfer $(160 \mathrm{mmhg})$ akan semakin menurun sekitar $37,5 \%$ menjadi 100mmHg (Sherwood, 2010). Dapat dibayangkan bila persentase gas $\mathrm{O}_{2}$ yang diberikan ke dalam chamber hanya $10 \%$, maka nilai $\mathrm{pO}_{2}$ di peredaran darah hanya sekitar 47,5 mmhg. Namun berdasarkan hasil pengukuran gas darah tikus, rata-rata nilai $\mathrm{pO} \quad{ }_{2}$ kelompok perlakuan sekitar $24 \mathrm{mmHg}$. Hal ini mungkin karena di dalam chamber tersebut terdapat 4 ekor tikus yang saling beruasha memperoleh $\mathrm{O}_{2}$ sebanyak mungkin, sehingga asupan $\mathrm{O}_{2}$ yang mereka peroleh pun semakin berkurang. Terlihat bahwa pemaparan gas $\mathrm{O} 210 \%$ selama 3 hari adalah nilai $\mathrm{pO}_{2}$ yang paling rendah dan kembali meningkat pada 7, 14, dan 21 hari. Peristiwa ini menunjukkan bahwa tikus berusaha mempertahankan hidup dengan melakukan hiperventilasi guna memenuhi kebutuhan $\mathrm{O}_{2}$. 
3. Profil Aktivitas Antioksidan Katalase Jaringan Hati Tikus

Pada tikus kelompok perlakuan, aktivitasantioksidan katalase tertinggi terjadi selama hari ke tiga dan semakin menurun pada pemaparan selama 7 dan 14 hari namun kembali meninggkat hingga 75,75 Unit/ml pada lama pemaparan 21 hari. Fungsi katalitik antioksidan katalase adalah mempertahankan homeostatis dari meningkatnya kadar ROS. Fungsi katalitik ini dapat diukur berdasarkan kemampuan antioksidan dalam mengubah substrat menjadi produk. Salah satu faktor yang mempengaruhi kerja enzim adalah kesesuaian antara konsentrasi antioksidan dan konsentrasi substrat (Pough et al., 2004). Bila dalam larutan konsentrasi suatu antioksidan besar maka akan semakin mempercepat kerja antioksidan tersebut sehingga semakin banyak pula produk yang terbentuk. Selain itu, banyaknya molekul substrat yang tersedia di dalam suatu larutan akan menentukan besarnya frekuensi reaksi subtrat terhadap enzim sehingga akan menentukan pula banyaknya produk yang terbentuk.

Aktivitas antioksidan katalase yang lebih rendah pada kelompok tikus kelompok perlakuan mungkin disebabkan oleh rendahnya konsentrasi antioksidan katalase yang dibentuk oleh jaringan hati pada hari tersebut. Bila dibandingkan aktivitas antioksidan katalase antara kelompok kontrol dengan kelompok perlakuan, kelompok perlakuan diperoleh aktivitas antioksidan katalase yang lebih besar namun cenderung menurun pada 7 dan 14 hari. Namun, aktivitas antioksidan katalase kembali meningkat ketika pemaparan 21 hari. Berdasarkan kondisi tersebut, saat 21 hari pemaparan hipoksik, tikus melakukan adaptasi untuk mempertahankan hidup. Selain itu, antioksidan katalase merupakan enzim yang bersifat reaktif terhadap substrat $\mathrm{H}_{2} \mathrm{O}_{2}$, mungkin karena katalase yang diukur dengan spektrofotometer adalah katalase yang belum rusak akibat pengaruh lingkungan.

4. Profil MDA Jaringan Hati Tikus

Berdasarkan data kadar MDA jaringan hati dapat diketahui bahwa baik dalam kondisi normal ataupun hipoksia tetap terbentuk MDA. Kelompok perlakuan menghasilkan kadar MDA yang lebih besar namun mengalami fluktuatif di setiap lama pemaparan hipoksik hipoksia. Kadar MDA mengalami penurunan pada pemaparan selama 3 hari sebesar 0,836 nmol/ml dan 14 hari sebesar 0,856 nmol/ml. Kadar MDAtertinggi terjadi pada lama pemaparan selama 7 hari sebesar $1,417 \mathrm{nmol} / \mathrm{ml}$. Terbentuknya MDA merupakan indikasi bahwa telah terjadi kerusakan jaringan akibat dari banyaknya keberadaan ROS. Kondisi hipoksia dapat menyebabkan meningkatnya kadar elektron-elektron bebas yang disebut pula sebagai ROS (Sahlin et al., 2010). Salah satu ROS yang dihasilkan oleh tubuh adalah $\mathrm{HO}_{2} \cdot{ }_{2}$ Molekul $\mathrm{H} \mathrm{O}_{2}{ }_{2}$ bersifat larut dalam lemak dan menyebabkan kerusakan pada membran sel. Kerusakan pada membran sel terjadi melalui proses peroksidasi lemak. Pada akhir peroksidasi lemak akan terbentuk senyawa aldehid berupa malondialdehid (MDA) (Catala, 2011).

Berdasarkan data kadar MDA kelompok perlakuan, terjadi fluktuatif kadar MDA pada setiap lama pemaparan $\mathrm{O}_{2}$ 10\%. Dapat dilihat bahwa pada lama pemaparan selama 7 hari terjadi kadar MDA yang paling tinggi, sehingga dapat diindikasikan bahwa pada hari tersebut paling tinggi pula ROS yang terbentuk. Hal ini juga didukung oleh aktivitas antioksidan katalase yang menurun pada pemaparan selama 7 hari. Pada pemaparan selama 14 hari kadar MDA menurun, hal ini mengindikasikan bahwa antioksidan katalase mampu menekan keberadaan ROS. Menurut penelitian yang telah di lakukan oleh Chen et al. (2007), salah satu dari berbagai jenis ROS yang melimpah saat kondisi hipoksia adalah $\mathrm{H}_{2} \mathrm{O}_{2}$. $\mathrm{H}_{2} \mathrm{O}_{2}$ ini bersifat reaktif terhadap membran sel. Antioksidan katalase diketahui sebagai antioksidan endogen yang berperan sebagai penyeimbang ketika kemampuan fisiologis menurun dalam melawan radikal bebas. Antioksidan katalase bertugas untuk mencegah rantai reaksi peroksidasi lemak dengan mengubah $\mathrm{H} \mathrm{O}$

menjadi $\mathrm{O}_{2}$ dan $\mathrm{H}_{2} \mathrm{O}$.

5. Hubungan Aktivitas Katalase dengan Kadar MDA

Katalase merupakan antioksidan endogen berjenis enzim yang bereaksi dengan molekul $\mathrm{H} \mathrm{O}$. Ketika keduanya membentuk kompleks substrat-enzim, maka reaksi osidasi akan terjadi sehingga $\mathrm{H}_{2} \mathrm{O}_{2}$ diuraikan menjadi $\mathrm{O}_{2}$ dan $\mathrm{H}_{2} \mathrm{O}$. Kelompok perlakuan tentang aktivitas katalase 
dengan kadar MDA, cukup berhubungan dikarenakan $\mathrm{H} \mathrm{O}_{2}$ merupakan salah satu jenis ROS yang melimpah saat hipoksia. Pada 3 hari pemaparan hipoksia aktivitas katalase meningkat bila dibandingkan dengan pemaparan 1 hari. Bila ditinjau pada kadar MDA pemaparan 3 hari, terlihat bahwa kadar MDA pada hari tersebut menurun. Peristiwa ini merupakan gambaran peran katalase dalam menekan ROS yang reaktif terhadap membran sel. Adapun peningkatan kadar MDA terjadi pada pemaparan 7 hari dan aktivitas katalase pada hari tersebut menurun. Peristiwa ini mungkin disebabkan tubuh tikus tidak mampu memproduksi antioksidan dengan optimal sehingga reaksi ROS dengan membran sel tidak dapat dihindari. Pada pemaparan 14 hari, aktivitas katalase semakin rendah dari 7 hari pemaparan serta kadar MDA pemaparan 14 hari menunjukkan penurunan bila dibandingkan dengan 7 hari pemaparan. Hal ini mungkin disebabkan oleh keberadaan antioksidan selain katalase yang mampu menekan ROS sehingga tidak terjadi kerusakan sel. Pada pemaparan 21 hari, baik aktivitas katalase ataupun kadar MDA terjadi peningkatan. Peristiwa ini menunjukkan bahwa dengan pemaparan gas $\mathrm{O}_{2}$ selama 21 hari ROS akan semakin meningkat namun pertahanan tubuh pun juga semakin meningkat, sehingga tikus-tikus yang ada di dalam chamber tetap dapat bertahan.

6. Analisis Hasil Uji Statistik.

Berdasarkan hasil uji statistik, pada jaringan hati tikus baik aktivitas katalase ataupun kadar MDA adalah Terima $\mathrm{H} 0$ yakni tidak perbedaan rata-rata terhadap lama pemaparan gas $\mathrm{O}_{2}$. Peristiwa ini mungkin disebabkan karena organisme akan berusaha mempertahankan hidupnya disaat kondisi lingkungan tidak menguntungkan. Namun, hasil ini tidak terjadi pada penelitianpenelitian sebelumnya, yang mengatakan bahwa pemaparan gas $\mathrm{O}_{2} 10 \%$ selama $1,3,7,14$, dan 21 hari menunjukkan perbedaan yang signifikan. Hal ini mungkin dikarenakan oleh ketahanan tikus yang digunakan dalam penelitian ini lebih tinggi dibandingkan dengan ketahanan tikus yang digunakan oleh penelitian sebelumnya. Sehingga perlu dilakukan penelitian lebih lanjut tentang aktivitas katalase dan MDA dengan menurunkan kadar gas $\mathrm{O}_{2}$ dan menambahkan lama pemaparan serta ditinjau pada organ tubuh lainnya.

\section{Kesimpulan}

Tidak terdapat pengaruh paparan hipoksia terhadap aktivitas antioksidan katalase dan kadar malondialdehid (MDA) pada jaringan hati tikus. Paparan hipoksia dapat menurunkan berat badan tikus. Paparan hipoksia dapat menurunkan nilai $\mathrm{pH}, \mathrm{pCO}_{2}$ dan $\mathrm{pO}$ plasma darah tikus.

\section{Daftar Pustaka}

Catala, A. (2011). Lipid Peroxidation. (INIFTA-CCT La Plata-CONICET), Facultad de Ciencias Exactas, UNLP.

Chen, X.Q., Dong, J., Niu.C.Y., Fan. J. M., Du. J.Z. (2007). Effects of Hypoxia on Glucose, Insulin, Glucagon, and Modulation by Corticotropin-Releasing Factor Receptor Type 1 in the Rat. Endocrine Journal; 148 (7) : 3271.

Ge., Wang., Yand., Lui. (2001). Progress in studying weight loss at high altitude and its potential application in patients with obesity. Qinghai: Research center for high altitude medicine.

Law, Rob dan Bukwirwa. (1999). The Physiology of Oxygen Delivery. Issue 10 (3): 1-2. Diunduh dari http://www.nda.ox.ac.uk/wfsa/html/u10/u1003_01.html pada tanggal 14 Desember 2011.

Sherwood, L. (2010). Human Physioloy From Cells to Systems 7th Edition. Canada: Brocks/ Cole.

Vallet, B., Teboul, J.L., Cain, S., Curtis, S. (2000). Venoarterial CQ difference during regional ischemic or hypoxic hypoxia. Journal Application of Physiology. Vol 89: 1317-1321. 